\title{
Л.А. Прохорова
}

\section{ГЕОЕКОЛОГІЧНІ УМОВИ ПІВНІЧНО-ЗАХІДНОГО РАЙОНУ КОНТИНЕНТАЛЬНОГО СХИЛУ ЧОРНОГО МОРЯ}

\author{
L.A. Prokhorova
}

\section{GEOECOLOGICAL CONDITIONS OF THE NORTH-WESTERN AREA OF THE CONTINENTAL SLOPE OF THE BLACK SEA}

Представлений фрагмент макета структури інформаційної системи «геоекологічні умови морського басейну». Наведені результати аналізу ряду даних про окремі складові субсистеми регіональних геолого-екологічних умов північнозахідного району континентального схилу Чорного моря з метою формування відповідного блока-компонента вказаної інформаційної системи. Результати морських, зокрема глибоководних, геоекологічних досліджень, спрямовані на всебічне інформаційне забезпечення прийняття оптимальних проектних і господарських рішень як на стадії формування морських техногенно-природних геоекосистем, так і під час їх функціонування.

Ключові слова: Чорне море, континентальний схил, геоекологічні умови.

Представлен фрагмент макета структуры информационной системы "геоэкологические условия морского бассейна». Приведены результаты анализа ряда данных об отдельных составляющих субсистемы региональных геологоэкологических условий северо-западного района континентального склона Черного моря с целью формирования соответствующего блока-компонента указанной информационной системы. Результаты морских, в частности глубоководных, геоэкологических исследований, направлены на всестороннее информационное обеспечение принятия оптимальных проектных и хозяйственных решений как на стадии формирования морских техногенно природных геоэкосистем, так и во время их функционирования.

Ключевые слова: Черное море, континентальный склон, геоэкологические условия.

A fragment of the structure model of information system "geoecological conditions of sea basin" is presented. The results of analysis of some data on the individual components of the regional geoecological conditions of the north-western area of the continental slope of the Black Sea subsystem are considered with the aim of building of the component of this information system. Results of the sea, in particular deep sea, geo-environmental studies are aimed at providing comprehensive information for making optimal design and business decisions at the stage of formation of technogenic-natural marine ecosystems, as well as during their operation.

Keywords: Black Sea, continental slope, geoecological conditions.

\section{ВСТУП}

Предметом досліджень $€$ регіональні геоекологічні умови північно-західного району континентального схилу Чорного моря. Відмітимо, що геоекологічні умови, в їх широкому розумінні, - це складна природна об'єктивна реальність, яка змінюється у часі і просторі. Оцінюється вона системою показників (характеристик, параметрів тощо), які відповідають завданням, що своїм вирішенням забезпечують досягнення конкретної поставленої мети. Підкреслимо, що коли морська інженерна геологія $€$ науковим напрямом, предметом дослідження якого $€$ інженерно-геологічні умови, тобто умови в основному літосферного сегменту будь-якого морського басейну або його частини, то поняття "геоекологічні умови", яке означає предмет морської геоекології, є більш широким. Воно, крім еколого-геологічної (геоекологічної) [9] складової умов функціонування, в даному випадку певної частини геоекосистеми Чорного моря, охоплює атмосферні та гідросферні умови суміжних з нею морських аеро- та акваекосистем. Доцільність включення різних характеристик зазначених морських геоекосистем в інформаційну систему "геоекологічні умови морського басейну" зумовлена їх роллю у формуванні кількісних і якісних характеристик компонентів-субсистем чорноморської морської геоекосистеми, що розглядається.

\section{РАЙОН РОБІТ, МЕТОДИ ТА ОБ'ЄКТ ДОСЛІДЖЕНЬ}

Акваторія досліджень розташована в зоні зчленування шельфу і глибоководної западини північно-західної частини Чорного моря. Ї̈̈ північна межа проходить трохи нижче брівки шельфу (ізобати 160-200 м), південна - близько 
43²0’ паралелі північної широти. Західна границя проходить по меридіану майже 31³0' східної довготи (див. рисунок).

Вперше наведено фрагмент макету структури інформаційної системи "геоекологічні умови морського басейну" (див. таблицю), і зроблено наголос на висвітленні геолого-екологічної складової геоекологічних умов досліджуваного району Чорного моря з метою створення відповідного блока зазначеної інформаційного системи. Підкреслимо, що результати як шельфових, так і глибоководних морських геоекологічних досліджень спрямовані на забезпечення прийняття оптимальних проектних і господарських рішень як на стадії формування морських техногенно-природних геоекосистем, так і в процесі їх функціонування.

Фізико-географічний блок-компонент системи геоекологічних умов північно-західного сектора континентального схилу Чорного моря. Фізико-географічний компонент $€$ важливою складовою системи геоекологічних умов, тому що визначає багато аспектів формування, дії та впливу практично всіх інших компонентів зазначеної системи.

Велику роль в геоекологічних умовах відіграють кліматична, гідрометеорологічна і гідрофізична складові системи фізико-географічного блока-компонента, основні характеристики яких можна знайти в спеціальній літературі [4, 5 та ін.].

Зазначені вище складові геоекологічних умов характеризуються режимами температури та атмосферного тиску, які у свою чергу, визначають пов'язані між собою, в більшою або меншою мірою режими вітрів, смерчів, туманів, хмарності, опадів, хвилювань тощо. Крім того, ці складові та їх режими впливають на характеристики коливань рівня моря, припливіввідпливів, зміни температур водної товщі як у різних частинах площі акваторії, так і по розрізу водної товщі. Зокрема, режим течій в районі досліджень, як і взагалі у Чорному морі, визначається в основному вітровим режимом, материковим стоком, розподілом щільності води,

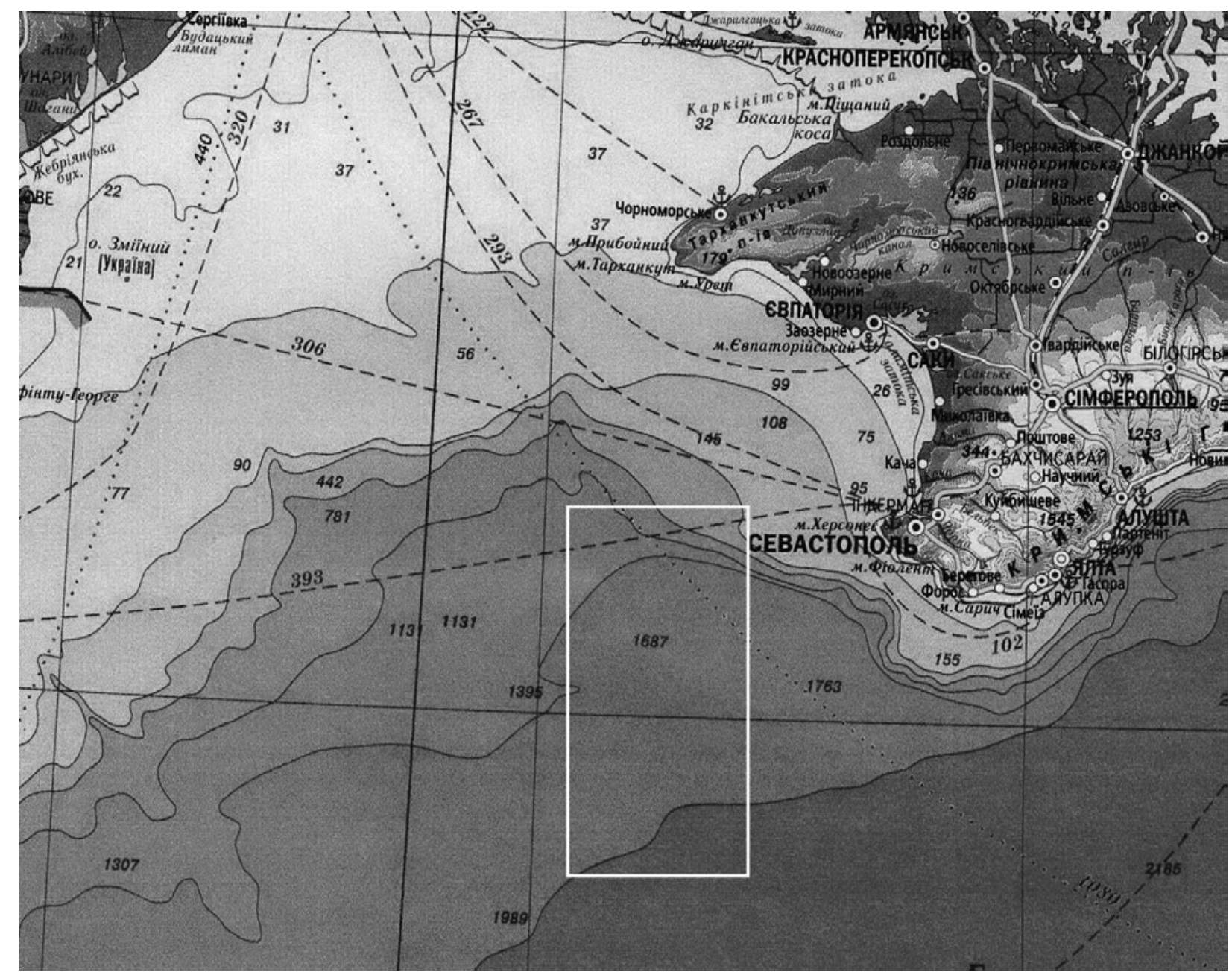

Рисунок. Оглядова схема розташування досліджуваної акваторії 


\section{Л.А. ПРОХОРОВА}

Таблиця. Фрагмент інформаційної системи (IC) "геоекологічні умови морського басейну»

\begin{tabular}{|c|c|}
\hline Субсистеми IC & Компоненти субсистеми IC \\
\hline $\begin{array}{l}\text { Морська природна геолого- } \\
\text { екологічна система }\end{array}$ & $\begin{array}{l}\text { Положення в регіональному геоекосистемному блоці: характеристики } \\
\text { границь (тривалість, форма, проникність) тощо. } \\
\text { Склад: фазовий, хімічний, мінеральний, агрегатний, гранулометричний, } \\
\text { біотичний тощо. } \\
\text { Складові компоненти: твердий - аутигенний, теригенний, еоловий; рід- } \\
\text { кий - підземні та порові води; газовий - екзогенний, ендогенний; біоген- } \\
\text { ний - живий, не живий тощо. } \\
\text { Властивості (необхідні для оцінки впливу на живу речовину, розрахун- } \\
\text { ки взаємодії з транспортними засобами, спорудами та механізмами): } \\
\text { фізичні, водно-фізичні, фізико-механічні, фізико-хімічні, динамічні, біоло- } \\
\text { гічні тощо. } \\
\text { Стратифікація: щільнісна, температурна, біологічна, динамічна, вікова, } \\
\text { геолого-екологічні комплекси-субсистеми тощо }\end{array}$ \\
\hline $\begin{array}{l}\text { Морська техногенна субсис- } \\
\text { тема геоекосистемного бло- } \\
\text { ка (інженерні споруди, ко- } \\
\text { мунікації, засоби розробки } \\
\text { корисних копалин тощо) }\end{array}$ & $\begin{array}{l}\text { Впливи на геологічне середовище і живий компонент: питомий тиск } \\
\text { на геолого-екологічне середовище, характер передачі навантажень, три- } \\
\text { валість впливу, особливості взаємодії з аквальним та повітряним серед- } \\
\text { овищами, а також живим компонентом, обмеження щодо пересування } \\
\text { в геолого-екологічному середовищі, на кордоні геолого-екологічного та } \\
\text { акваекологічного середовищ тощо. } \\
\text { Матеріали конструкцій: склад, властивості, схильність впливу геологічно- } \\
\text { го середовища та живого компонента, зносостійкість тощо }\end{array}$ \\
\hline $\begin{array}{l}\text { Морська } \quad \text { техногенно- } \\
\text { природна субсистема }\end{array}$ & $\begin{array}{l}\text { Положення в регіональному геоекосистемному блоці: характеристики } \\
\text { границі (тривалість, форма, проникність) тощо. } \\
\text { Склад: фазовий, хімічний, мінеральний, агрегатний, гранулометричний, } \\
\text { біотичний, технічний тощо. } \\
\text { Складові компоненти:твердий - аутигенний, теригенний, еоловий; рідкий } \\
\text { — підземні та порові води; газовий - екзогенний, ендогенний, біогенний } \\
\text { - живий, не живий, антропогенний (техногенний) тощо. } \\
\text { Властивості (необхідні для оцінки впливу на живу речовину, } \\
\text { розрахунки взаємодії з транспортними засобами, спорудами та } \\
\text { механізмами): фізичні, водно-фізичні, фізико-механічні, фізико-хімічні, } \\
\text { динамічні, біологічні тощо. } \\
\text { Стратифікація: щільнісна, температурна, біологічна, динамічна, вікова, } \\
\text { технологічна, геолого-екологічні комплекси-субсистеми тощо. } \\
\text { Впливи на геолого-екологічне середовище і живий компонент: } \\
\text { питомий тиск на геолого-екологічне середовище, характер передачі } \\
\text { навантажень, тривалість впливу, особливості взаємодії з аквальним та } \\
\text { повітряним середовищами, а також живим компонентом, обмеження } \\
\text { щодо пересування в геолого-екологічному середовищі, на границі геолого- } \\
\text { екологічного та акваекологічного середовищ тощо. } \\
\text { Матеріали конструкцій: склад, властивості, схильністьвпливугеологічного } \\
\text { середовища та живого компонента, зносостійкість тощо. }\end{array}$ \\
\hline $\begin{array}{l}\text { Процеси та явища в мор- } \\
\text { ських геолого-екологічних } \\
\text { системах }\end{array}$ & $\begin{array}{l}\text { Природні: сейсмічні, вулканічні, тектонічні, гравітаційні (зсуви, обвали, } \\
\text { осипи, опливи), ерозійні та карстові процеси, діагенез, гальміроліз тощо. } \\
\text { Антропогенні (техногенні): зміна стратифікації, скаламутнення осадів } \\
\text { і осадження суспензій, зміна умов проживання, складу та властивостей } \\
\text { бентосних гідробіонтів, зміна складу і властивостей компонентів геолого- } \\
\text { екологічного середовища, зсуви, обвали, осипи, опливи на схилах, в тому } \\
\text { числі під впливом їх підробки, ерозійні і карстові процеси, гальміроліз } \\
\text { тощо. }\end{array}$ \\
\hline
\end{tabular}


конфігурацією берегів і рельєфу дна. Вплив інших факторів помітно позначається лише в окремих районах акваторії.

При розподілі атмосферного тиску, близького до кліматичного, загальна схема поверхневих течій являє собою систему замкнутих переважно циклонічних кругообігів.

Геолого-екологічний (суто геоекологічний) блок-компонент системи геоекологічних умов північно-західного сектора континентального схилу Чорного моря характеризується сукупністю складових, серед яких головними слід вважати структурно-тектонічну, геологічну процесуальну, геоморфологічну, речовинну, геохімічну та складову властивостей.

Структурно-тектонічна складова геологоекологічного блока-компонента геоекологічних умов північно-західного сектора континентального схилу Чорного моря. Отримані на цей час матеріали дозволяють віднести район досліджень, як і всю північно-західну частину континентального схилу Чорного моря, до області відносно молодої (крейдяної) палеоострівної вулканічної дуги в зоні зчленування альпійських, байкальських та герцинських тектонічних структур. Континентальна окраїна в даному регіоні як тектонічна структура I порядку включає частину суші (аеральну зону), шельф, континентальний схил і континентальне підніжжя (підводна частина). Вся глибоководна западина Чорного моря розглядається як релікт континентального підніжжя Паратетіса. Районування, яке зараз прийнято фахівцями, засноване на аналізі геодинамічної природи найбільших геологічних тіл $[6,8,10]$.

Формування регіональних морфоструктур континентального схилу пов'язують 3 регіональними тектонічними процесами зокрема, до регіональних зон розломів приурочені каньйони, характерні форми яких зафіксовані і в районі досліджень. Про їх активну ерозійноденудаційну діяльність свідчать колосальні за своїми розмірами підводно-ерозійні амфітеатри, що спостерігаються на брівці континентального схилу. Маса еродованого матеріалу, яка перемістилася до підніжжя уступу схилу по долинах каньйонів, зумовила розвиток величезних полів накопичення цих продуктів у конусах виносу, що складають перехідну зону від континентального схилу до ложа западини.

Своєрідні форми рельєфу утворюються в областях активного газовиділення і проявів грязьового вулканізму [16]. Тут виділяються великі поля дрібногорбистого рельєфу й окремі конусоподібні сопки, найчастіше пов'язані з перегинами й уступами континентального схилу. Біля підніжжя схилу ділянки газовиділень зумовлюють формування своєрідних карбонатних споруд у вигляді трубкоподібних форм.

Результати досліджень у різні роки неотектонічних та сучасних рухів земної кори в Чорноморському регіоні, включаючи район досліджень, були використані при побудові схеми неотектонічних і сучасних рухів північнозахідної частини Чорного моря [9].

Основні головні структури сформовані в мезокайнозойському осадовому чохлі, з переважно широтною протяжністю, блоковим характером структур, які сформувалися внаслідок попередніх етапів тектонічного розвитку території. У південно-західній частині виділяється крайовий горст континентальної окраїни, перекритий потужним (до 2-4 км) мезокайнозойським чохлом моря.

Порівняльний аналіз сучасного та доголоценового рельєфів дозволяє стверджувати, що в його формуванні були задіяні глобальні регіональні, а також неотектонічні і сучасні геодинамічні процеси. Особливо яскраво ці фактори проявляються в області сучасного континентального схилу Чорного моря. Аналіз складових донної геоекосистеми четвертинного та голоценового віку свідчить про успадкований характер неотектонічних та сучасних рухів, а також про визначальну роль розломно-блокової структури шельфу, континентального схилу і глибоководної западини в розподілі потужностей і складів зазначених компонентів досліджуваної четвертинної палеогеоекосистеми як по площі, так і за віком.

Розгорнуті характеристики геологічної і тектонічної будови перелічених вище структур, за якими можна скласти уявлення про відповідні умови району досліджень, висвітлені в роботах $[1,8,10,12,14,19]$.

Геологічна процесуальна складова системи геоекологічних умов північно-західного сектора континентального схилу Чорного моря. Формування рельєфу континентального схилу і глибоководної западини Чорного моря, як і рельєфу земної поверхні в цілому, зумовлене взаємодією компонентів процесуальної складової системи геоекологічних умов, передусім ендогенних і екзогенних геологічніх процесів при підпорядкованому значенні останніх. Рельєфоутворююча роль цих процесів неоднозначна як 
за масштабами, так і за тривалістю впливу.

Для досліджуваної акваторії характерна активна діяльність підводних стічних і щільнісних течій, суспензійних потоків, що моделюють поверхні схилів і бортів каньйонів. Гравітаційне переміщення осадків обумовлено активізацією ендо- та екзогеодинамічних процесів, що викликають порушення рівноважного стану ухилів поверхні дна, а також перезволоженням донних осадків у верхів'ях каньйонів палеорічок на північно-західному шельфі Чорного моря. Перезволоження осадків пов'язано, найімовірніше, з постійно діючим субмаринним розвантаженням підземних прісних вод по палеодолинах і обводнених тріщинно-тектонічних зонах.

Гравітаційні процеси проявляються таким чином. Відбувається переміщення, сповзання незв'язаної маси або повільний текучий рух пластичних мулистих осадків у місцях, де ухили дорівнюють критичним значенням або близькі до них, а також вздовж долин і каньйонів. При швидкому переміщенні матеріалу виникають суспензійні потоки, що призводять до деструкції схилових поверхонь та акумуляції матеріалу у вигляді великих конусів виносу, валоподібних, акумулятивних тіл у підніжжя схилу.

Ерозійні та ерозійно-денудаційні процеси зумовлені дією комплексу факторів, серед яких велике значення мають підводні течії і суспензійні потоки, що викликають появу лінійних ерозійних врізів і підводних каньйонів у верхній і середній частинах схилу і здебільшого акумулятивних накопичень в його підніжжі.

Геоморфологічна складова геологоекологічного компонента геоекологічних умов північно-західного сектора континентального схилу Чорного моря. Континентальний схил у досліджуваному секторі Чорного моря складається з трьох ступенів, які характеризуються згладженим, слабогорбистим рельєфом і незначним ухилом у бік западини. Сходи починаються уступами на глибині 800-1000, 1500-1800 і 2000-2100 м. Підніжжя континентального схилу добре проявляється на глибинах 19002000 м слабопагорбистим рельєфом. Ложе моря більш-менш чітко окреслюється ізобатою 2000 м і характеризується винятковою вирівняністю. Найбільші глибини (близько 2200 м) встановлені в західній частині моря по лінії мис Херсонес - мис Керомпе, приблизно в 110115 км від південного берега Кримського п-ва, тобто за межами району досліджень.

у морфоструктурному плані схил є підвод- ним продовженням затопленої в результаті трансгресії великої алювіальної рівнини, геологічний розріз якої складається 3 глибоко занурених корінних порід, перекритих континентальними і морськими осадовими відкладами. Ухил, який найчастіше становить $2^{\circ}-3^{\circ}$, обумовлений моноклінальним заляганням корінних порід і різновікових континентальних осадових відкладів, що перекриті морськими осадками. Ширина схилу різна і змінюється в районі досліджень залежно від розташування підводних конусів виносу. у будові континентального схилу приймають участь великі ерозійні врізи - каньйони [15, 16 та ін.], які розчленовують всю поверхню схилу від верхньої брівки до його підніжжя, простягаючись і в межі ложа. Каньйони зазвичай мають U-подібну форму, ширину від 150 до 2500 м, глибину врізу до 400-500 м, а в окремих випадках і до 1000 м. На випрямлених ділянках проходження каньйонів їх борти мають симетричну форму, що пов'язано з боковою ерозією, яка веде до розширення врізу. Інтенсивність донної та бокової ерозії в каньйонах змінюється залежно від ухилів, геологічної будови території [9].

Речовинна складова геолого-екологічного компонента геоекологічних умов північнозахідного сектора континентального схилу Чорного моря. У розподілі різних типів донних геоекосистем (ТДГ) верхньоплейстоценголоценових відкладів перебігової зони від зовнішнього північно-західного шельфу до глибоководної западини Чорного моря в районі досліджень відмічено наявність різних їх варіацій як по літералі, так і по вертикалі, що в основному визначаються морфоструктурними умовами району та історією його геологічного розвитку [1, 17-21 та ін.]. У відкладах давньочорноморського віку, наприклад, визначено п'ять ТДГ, $з$ яких ТДГ мідієвих мулів розповсюджені лише на зовнішньому шельфі, алеврито-пелітові фазеолінові мули на зовнішньому шельфі, брівці схилу та у верхній його частині.

Щодо просторового розміщення виявлених ТДГ у районі досліджень варто відмітите таке. Найчастіше спостерігається вертикальне сполучення, при якому будь-який з ТДГ верхньочорноморських відкладів, крім ТДГ пелітових мулів, безпосередньо перекриває різноманітні типи ТДГ, за винятком ТДГ глин новоевксинського віку. Просторово цей варіант сполучення ТДГ обмежений зонами шельфу і верхньої частини континентального схилу, простягаючись пере- 
важно вздовж цих морфоструктурних елементів. Зазначимо, що ділянки із сполученням ТДГ верхньочорноморських мідієвих мулів з ТДГ новоевксинських пісків або черепашників, значно більші і потужніші на шельфі. На межі шельф - континентальний схил домінує більш складне сполучення ТДГ, яке характеризується послідовним нашаровуванням верхньочорноморських алевритово-пелітових фазеолінових мулів на ТДГ мідієвих мулів, що підстилаються ТДГ новоевксинських черепашників.

Переважно в нижній частині схилу простягається зона, в якій ТДГ верхньочорноморських коколітових мулів чи ТДГ алевритових коколітових мулів підстилаються давньочорноморськими сапропелевими мулами, під якими залягає ТДГ новоевксинських алевритових глин. Виявлено, що до зони сполучення саме цих ТДГ приурочено декілька достатньо великих ділянок, де на поверхню морського дна виходять ТДГ новоевксинських алевритових глин.

Від підніжжя схилу і глибше розповсюджений основний по площі вид сполучення ТДГ. Тут зазвичай ТДГ коколітових мулів, перекривають ТДГ сапропелевих мулів, що, у свою чергу, підстилаються ТДГ сапропелю, під яким залягає ТДГ новоевксинської глини. При цьому головним чином у північно-східному сегменті району спостерігаються переважно субмеридіонально орієнтовані стрічки й ареали, де замість ТДГ верхньочорноморських коколітових мулів розповсюджений ТДГ алевритових коколітових мулів.

На глибинах більш ніж 2100 м присутні ділянки, де ТДГ верхньочорноморських пелітових мулів залягають на ТДГ сапропелів, що перекривають ТДГ новоевксинських глин.

Склад відкладів, що формують ТДГ, їх розповсюдження, просторово-часова суперпозиція ТДГ, а також розподіл потужностей відкладів віддзеркалюють зміни умов седиментації і надають певні можливості для реконструкції історії геологічного розвитку та палеогеоекологічних умов у районі досліджень, що існували тут упродовж останніх близько 10-15 тис. років.

Геохімічна складова і складова властивостей геолого-екологічних систем, як складові геоекологічних умов північно-західного сектору континентального схилу Чорного моря. Геохімічний склад геолого-екологічної системи є дуже важливим показником геоекологічних умов, що існували в районі досліджень протягом останніх близько 10-15 тис. років. Відповідні характеристики наведені в роботах $[2,11,13]$.
Фізико-механічні, водно-фізичні та фізикохімічні властивості геолого-екологічних систем $[2,3] €$ не тільки інтегральними показниками багатьох складових геолого-екологічної системи та їх взаємодії, емерджентними характеристиками геоекологічних умов формування та функціонування цих систем, але й незмінною складовою всіх проектних робіт, що передують будь-якому законному освоєнню ресурсів геоекосистем, в тому числі тої, що розглядається.

Зважаючи на обмеженість об'єму статті, геохімічна складова еколого-геологічного компонента системи геоекологічних умов північно-західного району континентального схилу Чорного моря й складова властивостей донних геоекосистем як компоненти геологоекологічного блока системи геоекологічних умов північно-західного сектора континентального схилу Чорного моря, будуть висвітлені у подальших роботах автора.

\section{ВИСНОВКИ}

Вперше запропоновано фрагмент макета інформаційної системи «геоекологічні умови морського басейну".

Аналіз літератури, присвяченій різноманітним складовим геолого-екологічного блока як компонента інформаційної системи геоекологічних умов північно-західного району континентального схилу Чорного моря, показав, що геоекологічні умови, які існували в Чорному морі в районі досліджень впродовж останніх близько 10-15 тис. років, забезпечили певні види просторово-часових співвідношень різних сформованих і функціонуючих тут геологоекологічних систем.

У районі досліджень домінуючими серед факторів умов геоекогенезу з кінця новоевксинського часу були перенос речовини до континентального схилу, діяльність турбідитних потоків на схилі та його підніжжі, а також вертикальна біологічна зональність і нефелоседиментація.

Без підключення до процесу прийняття рішень інформаційної системи «геоекологічні умови морського басейну", тобто без знання геоекологічних умов за певний проміжок геологічного часу неможливо приймати оптимальні проектні рішення, зокрема щодо розроблення ефективних технологій освоєння матеріальних і просторових ресурсів у Чорному морі, в тому числі в районі досліджень. 


\section{Л.А. ПРОХОРОВА}

1. Архангельський А.Д., Страхов Н.М. Геологическое строение и история развития Черного моря. - М.; Л.: Изд-во АН СССР, 1938. - 226 с.

2. Бабинец А.Е., Митропольский А.Ю., Ольштынский С.П. Гидрогеологические и геохимические особенности глубоководных отложений Черного моря. - Киев: Наук. думка, 1973. - 160 с.

3. Бабинец А.Е., Емельянов В.А., Митропольский А.Ю. и др. Физико-механические свойства донных осадков Черного моря. - Киев: Наук. думка, 1981. - 204 с.

4. Блатов А.С., Булгаков Н.П., Иванов В.А. и др. Изменчивость гидрофизических полей Черного моря. - Л.: Гидрометеоиздат, 1984. - С. 8-11.

5. Богатко О.Н., Богуславский С.Г., Беляков Ю.М., Иванов Р.И. Поверхностные течения Черного моря. - Ceвастополь, 1979. - С. 26-30.

6. Герасимов M.E. К вопросу тектонического районирования Черноморского региона // Глубинное строение литосферы и нетрадиционное использование недр земли: Междунар. конф. - Киев, 1996. - С. 142144.

7. Гидрометеорология и гидрохимия морей СССР. Черное море. - Том 4. - Вып. 2. Гидрохимические условия и океанологические основы формирования биологической продуктивности. - Спб.: Гидрометеоиздат, 1992. -248 c.

8. Гончаров В.П., Непрочнов Ю.П., Непрочнова А.Ф. Рельеф дна и глубинное строение Черноморской впадины. - М.: Наука, 1972. - 157 с.

9. Емельянов В.А. Основы морской геоэкологии. Теоретико-методологические аспекты. - Киев: Наук. думка, 2003. - 238 с.

10. Земная кора и история развития Черноморской впадины / Под ред. Ю.Д. Буланже. - М.: Наука, 1975. -355 c.

11. Какаранза С.Д. Умови осадконакопичення перехідної зони від північно-західного шельфу до глибоководної западини Чорного моря в пізньоплейстоценголоценовий час:...Автореф. дис. канд. геол. наук. - К., 2007. - 24 c.
12. Милановский Е.Е. Проблема происхождения Черноморской впадины и ее место в структуре Альпийского пояса // Вестн. МГУ. Сер. геол. - 1967. - № 1. C. $8-15$.

13. Митропольский А.Ю, Безбородов А.А., Овсяный И.И. Геохимия Черного моря. - Киев: Наук. думка, 1982. $-144 \mathrm{c}$.

14. Муратов М.В. История тектонического развития глубокой впадины Черного моря и ее возможное происхождение // Изв. АН СССР. Сер. геол. - 1962. - №9. - C. 184-191.

15. Мельник В.І. Літодинаміка каньонів Чорного моря В плейстоцені-голоцені // Геология и полезные ископаемые Черного моря. НАН Украины. - К.: Карбон-ЛТД, 1999. - С. 272-275.

16. Мельник В.И. Мезоформы рельефа материкового склона западного и северного секторов Черного моря. - Киев, 1993. - 49 с.

17. Страхов Н.М. Современные осадки морей и океанов. - М.: Изд-во АН СССР, 1961. - 645 с.

18. Шимкус К.М., Емельянов Е.М., Тримонис Э.С. Донные отложения и черты позднечетвертичной истории Черного моря // Земная кора и история развития Черноморской впадины. - М., 1975. - С. 84-97.

19. Шнюков Е.Ф., Щербаков И.Б., Шнюкова Е.Е. Палеоостровная дуга севера Черного моря. - Киев: Чернобыльинформ, 1997. - 287 с.

20. Шнюков Е.Ф., Кутний В.А. Карбонатные образования как производное газовых выделений на дне Черного моря // Геофиз. журн. - 2003. - Т. 25, № 2. C. $90-100$.

21. Щербаков Ф.А, Куприн П.Н., Потапова Л.И. и др. Осадконакопление на континентальной окраине Черного моря. - М.: Наука, 1978. - 211 с.

Мелітопольський державний педагогічний університет ім. Богдана Хмельницького, Мелітополь

E-mail: eva@nas.gov.ua

Рецензент - чл.-кор. НАН України О.Ю. Митропольський 